\title{
COMMENTS
}

\section{JUDGMENTS: FRAUD AS A BASIS FOR RELIEF IN FEDERAL COURTS FROM FINAL STATE COURT JUDGMENTS}

$\mathrm{F}$

INAL JUDGMENTS frequently are not accorded the finality the term suggests, and their binding effect may be eviscerated in a number of ways. ${ }^{1}$ In appropriate circumstances these judgments may be nullified either directly or collaterally, and occasionally may be attacked via a hybrid proceeding. ${ }^{2}$ The following discussion assumes that a final state court judgment, valid on its face, is attacked in a federal court on the ground of fraud. ${ }^{3}$ The purpose of this comment is to identify the fraudulent conduct for which a federal court will grant relief from a final state court judgment and to ascertain the scope of the relief which may be granted.

\section{The ExTRINSic-InTRInsic Distinction}

It has generally been recognized that relief from a prior judgment will not be granted as a matter of course upon a mere showing

1 The binding effect of judgments may be avoided by: a new trial; altering, amending or vacating the judgment; moving for judgment notwithstanding the verdict; appeal; setting aside for mistake, inadvertance, surprise, excusable neglect, newly discovered evidence, or fraud; or enjoining enforcement. See FED. R. Crv. P. 60(b); 3 FreEMAN, JudGMENTS $\$ 1178$ (5th ed. 1925).

a A direct attack on a judgment is an attempt to avoid or correct it in some manner provided by law, in a proceeding instituted for that very purpose .... [I]f the action or proceeding has an independent purpose and contemplates some other relief or result, although the overturning of the judgment may be important or even necessary to its success, then the attack on the judgment is collateral." 49 C.J.S. Judgments $\S 408$ (1947).

One commentator has asserted that an independent action in equity to enjoin the enforcement of a valid judgment is not exactly a collateral or a direct attack, but might be termed an indirect attack because "the action recognizes that the judgment is valid, but seeks to establish certain conduct or matter that renders the enforcement of the valid judgment inequitable." 7 Moore, Federal Practice 7 60.25[2] \& n.16 (2d ed. 1955) [hereinafter cited as MOORE].

${ }^{3}$ Such assumptions ignore the difficult problems which are encountered in proceedings attacking prior judgments which arise from the determination of whether the prior judgment is or is not final; the record is complete and/or correct on its face; the tribunal was competent to hear the issue presented; the court had jurisdiction over the parties and the subject matter; the court was competent to render the judgment given; and the citizenship of the parties and the amount in controversy is appropriate to establish federal jurisdiction.

For an analysis of some of the current problems and well-reasoned suggestions for improvements in the law regarding attacks on final judgments see Comment, 66 Yare L.J. 526, 541-42 (1957). 
of the existence of fraud.4 This reluctance apparently is an outgrowth of the doctrine of res judicata, ${ }^{5}$ which precludes repeated litigation on the same issue by the same parties. In United States $v$. Throckmorton ${ }^{6}$ the Supreme Court laid down the general rule for granting relief from prior final judgments on the ground of fraud. The Court there was concerned with an attempt to avoid the effect of a final judgment on the ground that the judgment had been based in part on a forged document which had been admitted as evidence. In denying relief, the Court acknowledged that extrinsic or collateral fraud which prevented a losing party from fully presenting his case so that no real contest occurred would be sufficient to set aside a prior judgment, but held that fraud as to any matter which was actually presented and considered in the judgment assailed would be insufficient to support the attacking action. ${ }^{7}$

The fundamental basis for the Court's distinction appears to be in accord with the principle that a final judgment concludes all matters actually presented or necessarily considered in reaching the decision. ${ }^{8}$ Thus the Throckmorton case established an extrinsicintrinsic dichotomy which allowed relief from a fraudulently obtained judgment only in situations where the doctrine of res judicata

\footnotetext{
+E.g., 7 MOORE ๆ 60.37[1] nn.38 \& 39.

'For a comprehensive discussion of the doctrine of res judicata, see 2 Freesan, Judgments ch. XI (5th ed. 1925), wherein the author states: "When a matter is once adjudicated, it is conclusively determined as between the same parties and their privies; and this determination is binding as an estoppel, in all other actions, whether commenced before or after the action in which the adjudication was made." Id. $\$ 670$ at 1413-14.

- 98 U.S. 61 (1878).

" "But there is an admitted exception to this general rule [that an issuc once litigated to a final judgment will bar subsequent litigation on the same issue] in cases where, by reason of something done by the successful party to a suit, therc was in fact no adversary trial or decision of the issue in the case. Where the unsuccessfu! party has been prevented from exhibiting fully his case, by fraud or deception practised on him by his opponent .. . which show that there has never been a real contest in the trial or hearing of the case, are reasons for which a new suit may be sustained to set aside and annul the former judgment or decree, and open the case for a new and fair hearing. ... On the other hand, the doctrine is equally well settled that the court will not set aside a judgment becausc it was founded on a fraudulent instrument, or perjured evidence, or for any matter which was actually presented and considered in the judgment assailed. . . . [T] ]he acts for which a court of equity will on account of fraud set aside or annul a judgment or decree, between the same parties, rendered by a court of competent jurisdiction, have relation to frauds, extrinsic or collateral, to the matter tried by the first court, and not to a fraud in the matter on which the decree was rendered." Id. at 65-66, 68. (Emphasis added.)

${ }^{8}$ See note 5 supra.
} 
would not be violated. This concept has been expressly adopted in twenty-nine jurisdictions. ${ }^{9}$

In the subsequent case of Toledo Scale Co. v. Computing Scale Co., ${ }^{10}$ the Supreme Court failed to follow the extrinsic-intrinsic dichotomy established in Throckmorton and added a duplicitous category. In denying an injunction against enforcement of a prior judgment on asserted fraudulent grounds, the Court stated that an application of the extrinsic-intrinsic distinction was superfluous unless it was first found that the fraud charged prevented the complaining party from making a full and fair defense.11 Professor Moore, relying on a phalanx of authority, states that fraudulent conduct which prevents a party from fairly and fully presenting his claims or defenses is extrinsic fraud.12 It therefore appears that the Court in Toledo Scale Co., despite its refusal to apply the extrinsic or intrinsic labels, was actually following the Throckmorton distinction by predicating relief on a finding that the fraud charged prevented the presentation of a valid defense.

It has also been asserted that a position contrary to that of the Court in the Throckmorton case was taken when a similar question arose in Marshall $v$. Holmes. ${ }^{13}$ Referring to these two cases, one writer has stated:

The Supreme Court of the United States, to show its utter impartiality, has ruled both ways, and left the spectacle of two cases, one of which holds that false evidence is a ground for reversal, the other that it is not, both of which have been followed, and neither of which has ever been overruled.14

\footnotetext{
'Ariz., Ark., Cal., Ga., Idaho, Iowa, Ind., Kan., Ky., La., Md., Mich., Minn., Miss., Mo., Nev., N.J., N.M., N.Y., N.C., N.D., Ohio, Okla., Pa., S.D., Tenn., Tex., Utah, and Wash. See authorities cited note 4 supra; 49 C.J.S. Judgments $\$ 269$ n.3 (1947); 7 MOORE If 60.37[1] nn.38 \& 39.

10261 U.S. 399 (1923).

12 "We do not find ourselves obliged to enter upon a consideration of the sometimes nice distinctions made between intrinsic and extrinsic frauds in the application of the rule, because in any case to justify setting aside a decree for fraud whether extrinsic or intrinsic, it must appear that the fraud charged really prevented the party complaining from making a full and fair defense. If it does not so appear, then proof of the ultimate fact, to wit, that the decree was obtained by fraud, fails." Id. at 421.

12 "Fraud is extrinsic where a party is prevented by trick, artifice or other fraudulent conduct from fairly presenting his claim or defenses or introducing relevant and material evidence." 7 MOORE If $60.37[1]$ \& n.17.

${ }^{13} 141$ U.S. 589 (1891).

${ }^{1 *}$ Note, Fraud as a Basis for Setting Aside a Judgment, 21 Colvm. L. Rev. 268, 269 (1921).
} 
The distinction made in the above quotation occasionally has been accepted to mean that the Supreme Court has taken opposing positions on the validity of the extrinsic-intrinsic dichotomy. ${ }^{15}$ Such an interpretation appears patently erroneous for two reasons. First, assuming that these two decisions are incompatible, the conflict is not in regard to the validity of the extrinsic-intrinsic distinction, but to the application of the distinction to a particular set of facts: whether forged evidence admitted in the prior action is extrinsic or intrinsic fraud on the party against whom it was used. ${ }^{16}$ Secondly, it is by no means clear that the Court in Marshall v. Holmes held forged evidence to be extrinsic fraud. What the Court did hold was that a state court could not properly deny removal of a proceeding from a state court to a federal court if the general nature of the proceeding for which removal was sought was one of which the federal courts could rightfully take cognizance. The Court regarded an action to set aside a judgment in which the losing party had been fraudulently prevented from asserting a valid defense as being in the general nature of a proceeding of which a federal court could right. fully take cognizance under its equity power. Without passing on the merits of whether a forged instrument was or was not the type of fraud for which relief would be granted, the Court held, that once the general nature of the action was found to be within the cognizance of the federal court, it was for the federal court, not the state court, to determine whether the plaintiff was entitled to relief. ${ }^{17}$

As a result of these and other statements attributing opposing positions to the Court in the Throckmorton and Marshall decisions the validity of the extrinsic-intrinsic dichotomy is uncertain. ${ }^{18}$ The

${ }^{15}$ See Note, Relief in Federal Courts Against State Judgments Obtained by Fraud, 54 YALE L.J. 687, 693 n.20 (1945), and authorities cited therein.

${ }^{18}$ In the Throckmorton case the plaintiff sought to have a prior judgment set aside on the ground that it had been obtained through the admission into evidence of a forged deed; in Marshall $v$. Holmes the plaintiff sought to set aside the prior judgment on the ground that a letter authorizing her agent to contract for her, on which denial of recovery in the prior action was based, was a forgery.

17 "The suit being, in its general nature, one of which the Circuit Court of the United States could rightfully take cognizance, it was for that court, after the cause was docketed there, and upon final hearing, to determine whether, under the allegations and proof, a case was made which, according to the established principles of equity, entitled [plaintiff] to protection against the judgments alleged to have been fraudulently obtained." 141 U.S. at 601.

${ }^{18}$ E.g., Chicago, R. I. \& P. Ry. v. Callicotte, 267 Fed. 799 (8th Cir. 1920); Laun v. Kipp, 155 Wis. 347, 145 N.W. 183 (1914); Boring v. Ott, 138 Wis. 260, 119 N.W. 865 (1909). See 3 Barron \& Holtzoff, Federal Practice and Procedure \$ 1331 (rev ed. 1960) [hereinafter cited as Barron \& Holtzoff]; 3 FrReMAn, Judgments $\$ 1233$ (5th ed. 1925); Annot., 88 A.I.R. 1201 (1934). 
thrust of the decisions, however, appears to be aimed at creating a distinction which does not prostitute the res judicata doctrine. It may therefore be concluded, regardless of the application of the intrinsic label, that where the asserted fraud was considered or presented in the prior action, it will be an insufficient basis upon which to grant relief from the prior judgment.

The converse, however, does not necessarily follow. The mere fact that the issue of fraud presented in the attacking action was not, and could not have been, litigated in the prior action does not conclusively establish a right to relief. ${ }^{19}$ As an independent action to obtain relief from a prior judgment is limited to an equitable proceeding, ${ }^{20}$ relief will be granted only in accordance with general equitable principles. Consequently, even in situations where the doctrine of res judicata would not bar the subsequent judicial determination of the issue of fraud, courts nevertheless have refused relief under general equitable principles in cases where the disclosure of fraudulently concealed documents would not have changed the result, ${ }^{21}$ where the fraud did not prevent the presentation of a good defense, ${ }^{22}$ where the fraud would have been discovered but for the negligence of the complaining party, ${ }^{23}$ where the fraud caused no injury, ${ }^{24}$ or where the complaining party delayed an unreasonable length of time after discovering, or after he should have discovered, the fraud. ${ }^{25}$

\section{The Scope of Relief}

\section{Requirement for Independent Proceeding}

It is well settled that in appropriate cases the federal courts may grant relief from prior judgments obtained by fraud. ${ }^{26}$ When the judgment being attacked was rendered by a state court rather than another federal court, relief may be had only in an independent action which attacks the prior decree. This doctrine was clearly enunciated by the Supreme Court in Barrow v. Hunton..$^{27}$ In pass-

\footnotetext{
${ }^{10}$ See note 72 infra.

${ }^{30}$ See notes 33 \& 34 infra.

${ }^{21}$ Kithcart v. Metropolitan Life Ins. Co., 119 F.2d 497 (8th Cir. 1941).

22 Crim v. Handley, 94 U.S. 652 (1876).

${ }^{33}$ Sorenson v. Sutherland, 109 F.2d 714 (2d Cir. 1940).

sc Annot., 113 A.L.R. 1235 (1938), and authorities cited therein.

26 Grubb v. Public Util. Comm'n, 281 U.S. 470 (1930).

${ }^{20}$ Marine Ins. Co. v. Hodgson, 11 U.S. (7 Cranch) 332 (1813). See note 33 infra and accompanying text.

s7 99 U.S. 80 (1878).
} 
ing on the legality of removing to a federal court an action which attacked a prior state court judgment for fraud, Mr. Justice Bradley stated that a United States court could not properly entertain jurisdiction of a proceeding so connected with the original suit as to form an incident to it or a substantial continuation of it, but that an original or independent proceeding to set aside a decree for fraud might be within the cognizance of the federal court. ${ }^{28}$

Following this doctrine, the Supreme Court and the lower federal courts have repeatedly and consistently held that the federal courts cannot sit in review of state court judgments, but may prevent a party from benefiting from his fraudulently obtained judgment only in an independent equitable proceeding. ${ }^{20}$ This limitation of seeking relief via an independent action rather than an ancillary or supplementary proceeding presumably would require the re-enactment of all steps necessary to institute an original action. Process must be served and jurisdiction over the parties and the subject matter must be re-established. ${ }^{30}$

The requirement for an independent proceeding may create additional complications when the attacking action is first brought in the same tribunal, or a court of review of the same tribunal, which rendered the judgment being attacked, and thereafter is attempted to be removed to a federal court. A determination that the attacking action which is sought to be removed was brought as an original or independent action will be necessary to properly sustain the removal. This frequently may be difficult because of the fact that the tribunal from which removal is sought may be appropriate to hear either a supplementary or an independent attack on the decree which is to be vitiated. ${ }^{31}$

28 "If the proceeding is merely tantamount to the common-law practice of moving to set aside a judgment for irregularity, or to a writ of error, or to a bill of review or an appeal it would belong to [the category of a supplementary procecding so connected with the original suit as to form an incident to it, and substantially a continuation of it], and the United States court could not properly entertain jurisdiction of the case. ... On the other hand, if the proceedings are tantamount to a bill in equity to set aside a decree for fraud in the obtaining thereof, then they constitute an original and independent proceeding, and ... the case might be withln the cognizance of the Federal courts." Id. at 82-83.

${ }^{20}$ E.g., Simon v. Southern Ry., 236 U.S. 115 (1915); Howard v. DeCordova, 177 U.S. 609 (1900); Gaines v. Fuentes, 92 U.S. 10 (1875); Dulien Stcel Prods., Inc. v. Connell, 252 F.2d 556 (5th Gir. 1958); and United States v. Mashunkshcy, 72 F.2d 847 (10th Cir. 1934).

${ }^{30}$ See generally 1 BARRon \& HoLTzOFF, $\$$ 21-70.

${ }^{31}$ See generally 7 MOORE ๆ $60.39[1]$. 


\section{Restriction to Equitable Relief}

In 1813, the Supreme Court adopted the principle, derived from an early anonymous English case, ${ }^{32}$ that an independent action to obtain relief from a prior judgment is an equitable proceeding. ${ }^{33}$ The consistent pronouncements of the federal courts since that time have indicated that the principle of restricting the relief which a federal court may grant from a final state court judgment to equitable remedies and denying any action on the prior judgment directly has been accepted without opposition. ${ }^{34}$

The requirements which should exist before a federal court will exercise its equity power to prevent a successful party from utilizing a prior final judgment were succinctly stated in National Surety Co. v. State Bank:35

The indispensable elements of such a cause of action are (1) a judgment which ought not, in good conscience, to be enforced; (2) a good defense to the alleged cause of action on which the judgment is founded; (3) fraud, accident or mistake which prevented the defendant in the judgment from obtaining the benefit of his defense; (4) the absence of fault or negligence on the part of the defendant; and (5) the absence of any adequate remedy at law. ${ }^{36}$

This power of the federal courts appears to be expressly recognized in rule 60 (b) of the Federal Rules of Civil Procedure, which states in part:

${ }^{32}$ Anonymous, Litt. 37, 124 Eng. Rep. 124 (Ex. 1626). "If a judgment be given in an action at common law, the Chancellor may not alter or meddle with the judgment, but he may proceed against the person for corrupt conscience, because he takes advantage of the law against conscience." Ibid. Translated and quoted in English in 7 MOORE I 60.36, at 601 .

${ }^{33}$ Marine Ins. Co. v. Hodgson, 11 U.S. (7 Cranch) 332 (1813). "Without attempting to draw any precise line to which courts of equity will advance, and which they cannot pass, in restraining parties from availing themselves of judgments obtained at law, it may safely be said, that any fact which clearly proves it to be against conscience to execute a judgment, and of which the injured party could not have availed himself in a court of law; or of which he might have availed himself at law, but was prevented by fraud or accident, unmixed with any fault or negligence in himself or his agents, will justify an application to a court of chancery.

"On the other hand, it may with equal safety be laid down as a general rule, that a defence cannot be set up in equity, which has been fully and fairly tried at law, although it may be the opinion of that court, that the defence ought to have been sustained at law." Id. at 336.

st See, e.g., West Virginia Oil \& Gas Co. v. George E. Breece Lumber Co., 213 F.2d 702 (5th Cir. 1954); McSherry Mfg. Co. v. Dowagiac Mfg. Co., 160 Fed. 948 (6th Cir.), cert. denied, 214 U.S. 512 (1908); Sayers v. Burkhardt, 85 Fed. 246 (4th Cir. 1898), cert. denied, 172 U.S. 649 (1899).

35 120 Fed. 593 (8th Cir. 1903).

${ }^{30}$ Id. at 599. 
This rule does not limit the power of a court to entertain an independent action to relieve a party from a judgment, order, or proceeding .... .

The Applicable Law

The third significant consideration as to relief available in the federal courts from a prior final state court judgment evolves from the doctrine of Erie R.R. v. Tompkins, ${ }^{38}$ which directs that matters of substance, which are distingnished from matters of procedure, be determined by state law rather than federal law in diversity cases. In many proceedings attacking final state court judgments, the selection of the applicable law will be a moot problem because of the substantially similar results that would be reached under both sets of rules. However, the determination of the applicable law will not always be merely a theoretical problem, ${ }^{30}$ and in such situations the resolution of this question may well determine the right to relief. It therefore is essential to determine whether federal law or state law is applicable to such attacks.

It has frequently been indicated that the right to attack a prior state court judgment for fraud in an independent action is a substantive question, ${ }^{40}$ and therefore is controlled by state law. On the other hand, it has been asserted ${ }^{41}$ that the Erie doctrine is not applicable in independent actions attacking prior final judgments, on the ground that such attacks are matters of procedure. For example, in Griffith $v$. Bank of New York, ${ }^{42}$ in reversing the dismissal of an independent attack on a prior New York state court judgment, ${ }^{48}$ Judge Clark of the Court of Appeals for the Second Circuit, without citing any substantiating authority, stated:

But since the matters here involved are procedural, the doctrine of Erie R. Co. v. Tompkins [citations omitted] is not involved.44

\footnotetext{
${ }^{37}$ Fed. R. Civ. P. 60 (b). See 3 Barron \& Holtzoff $\$ 1331$.

ss 304 U.S. 64 (1938). See 7 MOORE 9 60.37[3].

${ }^{39}$ See, e.g., Griffith v. Bank of New York, 147 F.2d 899 (2d Cir. 1945); Laun v. Kipp, 155 Wis. 347, 145 N.W. 183 (1914).

${ }^{10}$ For example, in O'Boyle v. Bevil, 259 F.2d 506 (5th Cir. 1958), Judge Tuttle, speaking for the Court of Appeals, stated: "Questions as to the setting aside of judgments are difficult at best. This difficulty is increased when attack is made in a federal court on a state court judgment. There is one principle, however, that stands out clearly in this area of controversy. That is that in diversity cases, a federal court may set aside a state court judgment for equitable grounds that are recognized by the state as a basis for such action." Id. at 5I1-12.

${ }^{11}$ See Note, 54 Yale L.J. 687 nn.20 \& 25 (1945), and authorities cited therein.

42147 F.2d 899 (2d Cir. 1945).

${ }^{43}$ Bank of New York v. Kaufman, 26 N.Y.S.2d 474 (Sup. Ct. 1940), aff'd, 261 App Div. 818, 25 N.Y.S.2d. 408 (1941).

147 F.2d at 904.
} 
The weight of authority and the better reasoning seem to support the view that Erie requires the federal courts to grant or withhold relief in accordance with state law to avoid the spectacle of different results in the same state depending on whether the independent action is brought in a state or federal court. ${ }^{45}$ This reasoning coincides with the concept that the essential purpose of diversity jurisdiction in the federal courts is to provide another forum to determine the rights of the parties-not to create another body of law. ${ }^{46}$

The real character of the action to establish fraud is more clearly revealed by tracing the chain of consequences to its ultimate conclusion. The immediate purpose of the attacking action is to show fraud; the essential purpose of showing fraud is not to avoid the prior judgment, but rather to establish why an offense or defense which would have changed the allocation of rights in the previous action, was not then presented. Thus the showing of fraud does nothing more than provide the justification for admitting additional evidence after the conclusion of the prior proceeding. ${ }^{47}$ It may properly be said that the admission of evidence is a matter of procedure; however, the rules of admission and exclusion which operate to completely bar recovery in a suit brought in a state court bear vitally and not formally or negligibly on the state's policy regarding finality of local judgments. ${ }^{48}$ The determination which must be

${ }^{10}$ See Guaranty Trust Co. v. York, 326 U.S. 99 (1945); 7 MOoRe ff 60.37[3] at 633-34.

so "Diversity jurisdiction is founded on assurance to non-resident litigants of courts free from susceptibility to potential local bias. The Framers of the Constitution, according to Marshall, entertained 'apprehensions' lest distant suitors be subjected to local bias in State courts, or, at least, viewed with 'indulgence the possible fears and apprehensions' of such suitors. . . . And so Congress afforded out-of-State litigants another tribunal, not another body of law." Guaranty Trust Co. v. York, 326 U.S. 99, 111-12 (1945). Cf. Byrd v. Blue Ridge Rural Elec. Co-op., Inc., 356 U.S. 525, $536-39$ (1958).

${ }^{47}$ The mere showing of fraud does not entitle the complaining party to relief; it only entitles him to show that the previously adjudicated rights would have been allocated differently but for the fraud. Without first showing fraud (or other sinilar grounds for relief not considered herein) in the prior action, the complaining party will not be permitted to demonstrate that the prior allocation of riglits should be changed by introducing additional evidence of injury, a valid defense. See note 72 infra.

${ }_{48}$ "The nub of the policy that underlies Erie $R$. Co. $v$. Tompkins is that for the same transaction the accident of a suit by a non-resident litigant in a federal court instead of in a State court a block away should not lead to a substantially different result. . . . Plainly enougl, a statute that would completely bar recovery in a suit if brought in a State court bears on a State-created right vitally and not merely formally or negligibly. As to consequences that so intimately affect recovery or nonrecovery a federal court in a diversity case should follow State law." Guaranty Trust Co. v. York, 326 U.S. 99, 109-10 (1945). 
made in the context here considered is whether state or federal law shall prescribe the factors sufficient to disturb the finality of a state court's judgment.

It is submitted that Erie requires the federal courts to apply state law in a proceeding attacking a final state court judgment. When a state establishes limits within which a person may avoid the effect of a final decree of a state tribunal, absent contrary expression, relief beyond the specified limits is precluded by negative implication. A refusal by the federal courts to abide by these specified limits effectively creates additional rights and remedies to those granted by the state.49 Recognizing that such a result would be contrary to the purpose of diversity jurisdiction, ${ }^{50}$ the Supreme Court has held that the federal courts cannot grant relief to litigants when relief is barred in the state courts by statutes of limitations, negligence, ${ }^{52}$ failure to meet a burden of proof, ${ }^{53}$ and local applications of conflict of laws rules. ${ }^{54}$ Therefore, when a state creates a right to recover and then limits that right, either directly by refusing to allow an action to be brought after the lapse of a certain period of time, or impliedly by requiring the existence of certain conditions ${ }^{55}$ -for example the presence of extrinsic fraud-it seems clear that federal courts in diversity cases should follow state law.

Moreover, the arguments advanced in favor of applying federal law to independent actions seeking to set aside prior judgments for fraud are cursory and appear to be superficial. One commentator, for example, reasoned that the extrinsic-intrinsic dichotomy was procedural because it was used as a device for effecting the distribution of the power of review of judgments among various courts. ${ }^{50}$

' Where state law allows relief from final judgments only where extrinsic fraud is present, clearly the federal courts will be creating a new basis for relief if thcy permit the prior judgment to be set aside on a showing of intrinsic fraud only. On the other hand, a refusal to abrogate the binding effect of a final judgment upon a showing of intrinsic fraud when state law specifies that any fraud is sufficient to avoid a prior judgment is similarly creating an additional right to the victorious party in the prior action. This seems contrary to the Supreme Court's statement of the purpose of diversity jurisdiction of the federal courts. See note 46 supra.

${ }^{0}$ Ibid.

${ }^{81}$ Guaranty Trust Co. v. York, 326 U.S. 99 (1945).

82 Palmer v. Hoffman, 318 U.S. 109 (1943).

${ }^{58}$ Cities Service Oil Co. v. Dunlap, 308 U.S. 208 (1939).

${ }^{4}$ Klaxon Co. v. Stentor Elec. Mfg. Co., 313 U.S. 487 (1941).

Es Sce note 49 supra.

${ }^{56}$ Note, Relief in Federal Courts Against State Judgments Obtained by Fraud, 54 YALE L.J. 687, 693-94 (1945). This reasoning developed as a result of the writcr's attempt to justify the remark of Judge Clark in Griffith $v$. Bank of New York thit 
His conclusion appears to be based on the assumptions that intrinsic fraud excludes review by a different tribunal by limiting such an attack within the framework of the original action and its ancillary proceedings, and that extrinsic fraud excludes review by the same tribunal because such an attack is an independent, rather than an ancillary or supplementary, proceeding.5T To the contrary, some states require that all direct attacks on prior judgments be brought in the same court which rendered the judgment. ${ }^{58}$ The acknowledgment that intrinsic fraud limits review to an ancillary or supplementary proceeding is itself a recognition that intrinsic fraud will not support an independent action for relief from a prior judgment. The corollary to this acknowledgment obviously is that extrinsic fraud will support the independent action. The writer's reasoning appears to ignore this fundamental basis for the distinction-that extrinsic fraud will support an independent action while intrinsic fraud will not-and seems to assume that relief from a final judgment for intrinsic fraud is denied because the distinction limits him to courts which may properly hear ancillary or supplementary proceedings. It is submitted that it is the determination of the right to relief which requires the application of state law and that the ascertainment of a proper court to hear the action is merely a collateral matter following the initial determination.

The same commentator asserted that as a result of Marshall $v$.

such attacks were not covered by the Erie doctrine because they were matters of procedure. 147 F.2d 899 at 904 (2d Cir. 1945).

E7 "This view [that the necessary fraud for setting aside prior judgments is a matter of procedure] gains support from the fact that the right to seek review of a judgment generally depends on whether the injured party had the opportunity of bringing before the court in the original action the facts and issues that constitute fraud. If he had, the policy of avoiding relitigation would generally cause the review to be limited by the framework of the original action and its ancillary proceedings, excluding any action before a different tribuinal; the latter would be appropriate only when the fraud itself prevented the litigant from fairly presenting the facts in his favor to the original court. Consequently, the classification of fraud resolves itself into a determination of which court is the proper one for the case to be brought in, and the dichotomy between 'intrinsic' and 'extrinsic' fraud becomes a device for effecting a distribution of the power of review over judgments." Note, 54 YALE L.J. 687, 693 (1945).

${ }^{88}$ See, e.g., Duncan Coffee Co. v. Wilson, 139 S.W.2d 327 (Tex. Civ. App. 1940), where the court held that a direct attack on a final judgment rendered in a Texas court could be brought only in the same court which rendered the judgment being attacked; and an action otherwise qualifying as a direct attack, but brought in a different court will be considered collateral rather than direct. For a general discussion of the Texas rule see Hodges, Collateral Attacks on Judgments (pts. I-2), 41 TEXAs L. Rev. 163, 499 (1962-1963). 
Holmes $^{59}$ the Supreme Court was committed to a rejection of the extrinsic-intrinsic dichotomy ${ }^{60}$ Consequently, an incongruous situation is presented from which the author provides no escape: The extrinsic-intrinsic distinction is a matter of procedure under state law because the distinction is used to allocate the power of review. Since it is a procedural matter, federal law rather than state law is applicable. Under federal law, however, the distinction is not used to allocate the power of review, which is the only basis for defining it as procedural, because federal law does not recognize the distinction. Therefore, under federal law the assertion of fraud must be substantive, which requires the application of state law in diversity cases.

\section{CONCLUSION}

A federal court may, in appropriate cases $^{61}$ where it has jurisdiction as a result of diversity of citizenship, grant relief from a prior final judgment of a state court. The better view, under the Erie doctrine, is that in diversity cases where there is no federal question involved, ${ }^{62}$ a federal court may grant relief if the proceeding had been brought in the proper state court. This view is based on the theory that the diversity jurisdiction of the federal courts is merely to provide another tribunal for the settlement of contested rights and is not to create another body of law within a state. ${ }^{63}$ Therefore, to grant relief in a federal court when no similar relief is available

141 U.S. 589 (1891). See notes 16 \& 17 supra and accompanying text.

${ }^{\circ 0}$ Note, 54 Yale L.J. 687 n.20 (1945).

'1 See discussion accompanying note 3 supra.

a2 Closely related to the problem here under consideration is a question of federal constitutional law which must be distinguished. The problem arises from the "due process of law" requirement of the fourteeuth amendment and is found in situations where the judgment being attacked is void rather than voidable. Where, for example, the prior court had no jurisdiction of the parties or the subject matter, the action attacking that judgment may properly be brought in the federal courts without regard to state law. In such situations, however, the procceding has substantially changed from a diversity case to a federal question case.

For a discussion of, and suggested solutions to, some of the problems raised by applying the void-voidable distinction to direct and collateral attacks see Comment, 66 Yale L.J. 526 (1957). See Daniels v. Thomas, 225 F.2d 795 (10th Gir. 1955), where the court of appeals stated: "It is a principle as old as our dual state and federal judicial systems that a federal court is without jurisdiction to interfere with a judg. ment in a state court action in which the state court had jurisdiction of the subject matter and the parties thereto. It is only when the judgment of a state court is void either because that court lacked jurisdiction of the subject matter or of the parties to the action, or because it entered a judgment which it had no power to enter under the law, that such judgment may be reviewed in a federal court." Id. at 797.

is See note 46 supra. 
in the state courts would abrogate this rule and effectively create an additional remedy rather than merely an additional tribunal. ${ }^{64}$

Diversity cases in federal courts attacking prior state court judgments are limited, however, by virtue of the fact that the federal courts have not been given a power of review over state court judgments. ${ }^{85}$ Consequently, any proceeding attacking a state court judgment cannot be supplementary or ancillary but must be an independent action. ${ }^{\circ}$ The independent action attacking the validity of a prior judgment is an equitable proceeding; ${ }^{67}$ therefore, a federal court cannot act directly on the judgment by amending, annulling or vacating it, but rather is limited to acting on the parties in accordance with general equitable principles. ${ }^{88}$

The application of these general equitable principles has led the courts to distinguish between extrinsic and intrinsic fraud. ${ }^{69}$ This dichotomy recognizes the principles embodied in the doctrine of res judicata ${ }^{70}$ by defining intrinsic fraud as fraud which was actually presented or necessarily considered in the prior action, and extrinsic fraud as a collateral matter which was not previously in issue. ${ }^{71}$ After finding the existence of the proper kind of fraud, a federal court will otherwise grant relief only in accordance with other general principles of equity. ${ }^{72}$

Despite the prevailing view that state law will govern in granting relief from a prior state court judgment, ${ }^{73}$ the development of the extrinsic-intrinsic dichotomy in the federal courts is significant be-

\footnotetext{
os Cf. text accompanying note 49 supra.

OS For an excellent discussion of this matter pointing out that diversity jurisdiction rests in the discretion of Congress to determine at what time and upon what conditions the power may be invoked see Gaines v. Fuentes, 92 U.S. 10, 17-18 (1875).

oo See note 28 supra.

o7 See notes 32 \& 33 supra.

as Ibid.

${ }^{\circ}$ See note 7 supra.

${ }^{70}$ "The principle of res judicata 'that suits may not be immortal, while men are mortal' is given primacy by Throckmorton over the principle of individual justice, which, in theory at least, might be better achieved through the process of relitigation." 7 MOORE I 60.37[1] at 609 .

72 See note 7 supra and accompanying text.

72 Thus, in addition to extrinsic fraud, the complaining party must show: that the judgment rendered is inequitable, Kithcart v. Metropolitan Life Ins. Co., 119 F.2d 497 (8th Cir. 1941), and Annot., 113 A.L.R. 1235 (1938), and authorities cited therein; that a valid defense was available, Crim v. Handley, 94 U.S. 652 (1876); that he was not at fault or negligent in failing to present his defense, Grubb v. Public Util. Comm'n, 281 U.S. 470 (1930); and that the defense was not presented because of the fraud of the other party, Sorenson v. Sutherland, 109 F.2d 714 (2d Cir. 1940).

${ }^{73}$ See note 9 supra.
} 
cause it has been followed closely by the state courts. ${ }^{74}$ Regardless of the state's acknowledged acceptance or rejection of the federal extrinsic-intrinsic dichotomy, the results are likely to be similar because of the application of general equitable principles, only a part of which are embodied in the res judicata doctrine upon which the extrinsic-intrinsic distinction is based.

747 MOORE If 60.37[1] \& $\mathrm{n} .39$. 